\title{
Nurturing Islamic and Socio-political Thoughts in Riau and Beyond: Exploring Raja Ali Haji's Works
}

\author{
Helmiati*
}

\begin{abstract}
Raja Ali Haji is best-known as the author of the famous poem "Gurindam Dua Belas," even though he authored some other important poetries and proses that are often overlooked. In fact, he wrote a vast number of subjects in a variety of literary genres ranging from culture, history, politics, and jurisprudence to language. While other researchers such as Junus, Putten, Andaya, and Syam, have been concerned mainly with his works on culture, history, language, and jurisprudence, this study explores his works on Islamic and socio-political thoughts. Employing content analysis of relevant manuscripts and books, this study finds that Raja Ali Haji played various roles including as a religious scholar and a political thinker who synthesized culture and politics with Islam and whose thoughts have been extensively influential, mainly in Riau and beyond. This finding weakens the earlier assumption that Al-Mawardi political thoughts were more influential in the Malay world.
\end{abstract}

Keywords: Raja Ali Haji, Riau Malay kingdom, socio-political thoughts, Islamic thought, work

\section{Introduction}

Raja Ali Haji (RAH) is greatly an important figure in both politics and intellectuality in Riau Malay kingdom. In practical politics, he was one of the noble sons that was trusted to charge state duties. In his 32 years old, he occupied the regent and at the same time appointed successively as the adviser of the $8^{\text {th }}$ to $10^{\text {th }}$ Riau Junior Majesty (RJM). ${ }^{1}$ In the field of intellectuality, he produced many works in various disciplines ranging from culture, history, politics, and jurisprudence to language. However, he has been best-known as a poet as he is the author of the most well-known Malay poetry, "Gurindam Dua Belas," which contains great rhythms, meaningful values, and guidance for a human being derived from Islamic teachings. ${ }^{2}$ The poem has raised his name but has overshadowed his other achievements as people know him better as a poet. In fact, there are many passages in his other works that contain Islamic and socio-political thoughts that are very useful for ruling elites and Muslim society in the modern era.

As far as on RAH's thoughts are concerned, many studies have been done. Most of them were in the field of literature and culture like those belong to Putten, ${ }^{3}$ Syam, ${ }^{4}$ Maier, ${ }^{5}$ Putten and Azhar, ${ }^{6}$ Palawa ${ }^{7}$ and Junus. ${ }^{8}$ While Malik and Syanti looked at RAH's thoughts in relation to education, ${ }^{9}$ Palawa examined RAH's ethnical and Sufistic thoughts in politic. ${ }^{10}$ Andaya and Matheson elucidated how RAH's works were deeply rooted in Malay traditions and Islamic literature. ${ }^{11}$ However, these studies

\footnotetext{
* Helmiati (Ph.D), Senior Lecturer, Universitas Universitas Islam Negeri (UIN) Sultan Syarif Kasim Riau, Indonesia. Email: emikahar@yahoo.com.

${ }^{1}$ RJM was the real power in the kingdom who drove the government; meanwhile, Sultan (the Great Majesty) was mere as the symbol of power. Abu Hasan Sham (1996), "Karya Raja Ali Haji: Tinjauan dari perspektif Hukum,” Seminar paper in celebrating Raja Ali Haji's day, Pulau Penyengat, 31 October 31, p. 4.

2 Abdul Malik and Isnaini Leo Shanty (2017), "Personal Character Index in the Works of Raja Ali Haji," International Journal of Information Technology and Business Management, Vol. 58, No.1.

3 Jan van der Putten (1997), "Versified Awai Verified: Syair Awai by Raja Ali Haji," Indonesia and the Malay World, Vol. 72, pp. 99-133.

${ }^{4}$ Abu Hassan Syam (1993), Puisi-puisi Raja Ali Haji, Kuala Lumpur: Dewan Bahasa dan Pustaka.

${ }^{5}$ Hendrik M. J. Maier (2001), "Raja Ali Haji dan Hang Tuah: Arloji dan Mufassar," SARI : Jurnal Alam dan Tamadun Melayu, Vol. 19, No. 1, pp. 159-178.

${ }^{6}$ J. Putten and Al Azhar (1992), "Four Malay letters from Raja Ali Haji to Von De Wall," Bijdragen tot de Taal-, Land- en Volkenkunde I Journal of the Humanities and Social Sciences of Southeast Asia, Vol. 148, No. 3, pp. 521-528.

7 Alimuddin Hassan Palawa (2003), "The Penyengat School: A Review of the Intellectual Tradition in the Malay-Riau Kingdom," Studia Islamika, Vol. 10, No. 3, pp. 95-123.

${ }^{8}$ Hasan Junus (2002), Raja Ali Haji: Budayawan di Gerbang Abad XX, $2^{\text {nd }}$ edition, Pekanbaru: Unri Press.

9 Abdul Malik and Isnaini Leo Shanty (2017), "Personal Character Index in the Works of Raja Ali Haji," International Journal of Information Technology and Business Management, Vol. 58, No.1.

${ }^{10}$ Alimuddin Hassan Palawa (2020), Pemikiran Politik Raja Ali Haji Perspektif Etis dan Sufistik, Depok: Rajawali Pers.

${ }^{11}$ Barbara W. Andaya \& Virginia Matheson (1979), "Islamic Thought and Malay Tradition: The Writing of Raja Ali Haji of Riau (ca. 1809ca. 1870)," in Perception of the Past in Southeast Asia, Anthony Reid \& David Marr (eds.), Singapore: Heinemann Education Book [Asia] Ltd.
} 
are not adequate to describe RAH's roles as a Muslim and political thinker and his influence in Riau Malay and neighboring states. Therefore, this study is significant as it seeks to provide a contribution to the growing body of literature about this issue.

\section{Raja Ali Haji's Islamic Thoughts}

Religious and moral messages color the entire works of RAH in both prose and poem as Al-Qur'an and Sunnah serve as his main references. ${ }^{12}$ Theological thoughts can be found in his history book, Tuhfat al-Nafis, which expresses that the theme of human responsibility permeates the entire text. He states: "The will of Allah places limits on the personal freedom of man directs the line of history, but human is the factor which shapes specific episodes and determine the intricacies of man's relationship with his fellows." 13

Thus, man has free-will and free-act. While the will and Almightiness of God predestinated the human fate, he called it "takdir" (divine decree). RAH argues that "human failings and disavowal of God's law [sunnatullah] is the basic cause behind the tribulations and conflicts which beset society." 14 Therefore, it can be assumed that the RAH's theological current was not Jabariyah (fatalism), but Qadaryiah (free will) that emphasizes on the importance of a personal effort. However, as Andaya and Matheson mention: "Tuhfat al-Nafis is not only a historical epic, but a statement of belief, in which theological and ethical argument, is applied to an account of the past. The lessons which it contained were intended both for the common man and for the ruler himself." 15

RAH's thoughts on Islamic jurisprudence were frequently found in his poetic works. Syair Hukum Nikah opens with a brief doxology, and a verse describing that the poem was written to be a benefit to rulers, ministers, and officials. The poem contains some sections, each of which consists of a particular aspect of Muslim marriage law, such as the ceremony and dowry, behavior of women, separation, adultery, custody, and care of dependents and alimony ${ }^{16}$ In this poem, RAH provides a manual on marriage based on Islam that guides the physical and mental treatment of married couples. According to Hamidy, the excellence of this poem lays in the RAH's dare in expressing a sexual relationship between married couples. He delivered the techniques of copulation through a beautiful poetic style so that the expression is nether vulgar and nor indecent. Such expressions are important due to the issue of sexual education among "the Eastern" and the Malay world was never given openly, but by the metaphoric way. ${ }^{17}$ His other poem, Syair Siti Shianah, is a didactic poem describing rules for women in their daily life, including the way of treatment to the husband on the basis of Islam. ${ }^{18}$

RAH's other work, Tsamarat al-Muhimmah, also contains a lot of religious advice, besides civics law. Here, RAH clarifies the mystic element that is found in Gurindam Duabelas. For example, "Barang siapa yang mengenal yang empat, maka itulah orang yang ma'rifat" (whoever knows the four, then he who has deep knowledge). In a further comment, RAH explains that "the four" are Allah, human himself, mundane life, and the hereafter. ${ }^{19}$ Therefore, it is no wonder that Abdul Hadi W. M identified RAH as a "mystic poet." 20

RAH maintains that moral is closely connected with language. It was a reason why he compiled the text entitled Bustan al Katibin in preserving the Malay language. ${ }^{21}$ For him, language is an expression of a good manner and great morals. He poetically states "Jika hendak mengenal orang berbangsa, lihat kepada budi dan bahasa" (If you want to know people of a nation, look at their excellent mind

\footnotetext{
${ }^{12}$ Fakhrunnas MA. Jabbar (1985), "Catatan Malam Raja Ali Haji: Mengarang dengan Rujukan al-Quran dan Hadis,” Berita Buana, Tuesday, 21 May.

${ }^{13}$ Raja Ali Haji (1965), Tuhfat al-Nafis, Enche Munir Ali (trans.), Singapore: Malaysian Publications Ltd., pp. $203-207$.

${ }^{14}$ Andaya \& Matheson (1979), "Islamic Thought and Malay Tradition," p. 117.

15 Andaya \& Matheson (1979), "Islamic Thought and Malay Tradition," p. 124.

${ }^{16}$ Raja Ali Haji, Syair Hoekoem Nikah, Univ. Bibliotheek Leiden, Cod. Or. Klinkert, p. 174.

${ }^{17}$ UU Hamidi et al. (1986), Syair Suluh Pegawai (Hukum Nikah) Karangan Raja Ali Haji, Pekanbaru: Departemen Pendidikan dan Kebudayaan, pp. 11-12.

${ }^{18}$ Raja Ali Haji (1983), Syair Siti Shianah, Pulau Penyengat: Yayasan Kebudayaan Indra Sakti, Koleksi Naskah, no. A 13.

${ }^{19}$ Raja Ali Haji (2000), Gurindam Dua Belas, Pekanbaru: UNRI Press.

${ }^{20}$ Abdul Hadi W. M. (1985), Sastra Sufi: Sebuah Ontologi, Jakarta: Pusataka Firdaus, pp. 96 \& 240.

${ }^{21}$ Raja Ali Haji (1983), Bustan al Katibina Lis Subyanil Muta'allimin, Pulau Penyengat: Yayasan Kebudayaan Indera Sakti, Koleksi Naskah, no. 19.
} 
Nurturing Islamic and Socio-political Thoughts in Riau and Beyond (Exploring Raja Ali Haji's Works) and heart). ${ }^{22}$ In this poem, he seems to argue that 'budi' (excellence of mind and heart), as well as 'bahasa' (right behavior and refined language), are like two sides of the same coin. They are complementary sides of being a real Malay. In short, language is one of the notions of fine conduct and a standard to be considered as Malays of great lineage. ${ }^{23}$

Slightly further, RAH also launched a Malay dictionary, Kitab Pengetahuan Bahasa, meant to guide society in improving their comprehension of language, religion, proper conduct and behavior. In this book, he criticizes Malays who dressed in Dutch, English and Chinese styles, so that it would be difficult to identify whether they were Malays. ${ }^{24}$ In his eyes, Malays had looked very elegant and handsome since they dressed in their traditional styles. However, he did not find them dressing in the traditional dress anymore. He also criticizes those Malays who adopted European styles as they attired only pants without any t-shirt (berseluar bulat). At the same time, he also protests those Malays who spoke and wrote wrongly by saying 'pergi' (to go) as "pigi"; imitating the imperfect utterance of Chinese who mentioned 'udang' or 'olang' in preference to 'orang' (man). ${ }^{25}$

In this dictionary, RAH also explains the meaning of some words referring to bodily functions and sex so that users would know in which they are used. He provides them with contexts when and where to use them in an appropriate manner and moral. Putten stated: "he incorporates and elaborates on words referring to bad traits and misconduct to show the readers how they should not behave." ${ }^{26}$ This is also one of his efforts to recover some of Malay great prestige by providing an environment of considerably literate and religious society.

Concerning the instability and poverty of Riau in his era, according to RAH, it was due to man's failure to obey the Prophet's teaching and his reluctance to fight against the weakness of his own nature. The disintegration in the kingdom did not move at the behest of divine decree and was not caused by misrule. Rather, they were the result of mankind's wish to follow his lust, of which the most destructive were arrogance and stubbornness. ${ }^{27} \mathrm{RAH}$ then invites people to learn from these lessons and to emulate the actions of devout men. He argues that the past represented the accumulated learning of centuries in establishing traditions of correct conduct and providing examples of pious lives. Ignoring this fact meant discarding 'akal' which in turn paving the way for the triumph of the lust. ${ }^{28}$

\section{Raja Ali Haji's Islamic Socio-Political Thoughts}

The involvement of RAH in the Kingdom and community service was very intense. He combined the two roles of a literary figure and a leading advisor to RJM for over forty years. As a literary figure, his works ranged from political tracts, law, culture, and history to poetry and Malay dictionaries. Two works specifically discuss his socio-political thoughts; Tsamarat al Muhimmah and Muqaddimah fi Intizham Wazhaif al-Muluk. These two works on the political ethics of the ruler demonstrate that he was a political thinker who aimed to synthesize politics and culture with Islam.

While Muqaddimah fi Intizham shows how aspects of Islamic jurisprudence were applied to specific situations in Riau, Tsamarat al Muhimmah is his extensive discussion on the concept of kingship from an Islamic perspective, detailing its legal status, its required preconditions and the qualifications of a ruler, procedures for his appointing, and the establishment of a legal system. ${ }^{29} \mathrm{He}$ remarks that establishing kingship is collective compulsory (fardhu kifayah), i.e. a syar'i obligation. ${ }^{30}$ It means that the Muslim community as a whole must be responsible to establish kingship and to obey its authority. Here, he aims to give stronger weight to the legitimacy of the king so that all citizens

\footnotetext{
${ }^{22}$ Raja Ali Haji (2003), Gurindam Dua Belas.

${ }^{23}$ Raja Ali Haji (1983), Bustan al Katibina Lis Subyanil Muta'allimin, Pulau Penyengat: Yayasan Kebudayaan Indera Sakti, Koleksi Naskah, no.19, p. 7; Raja Ali (2003), Gurindam Dua Belas.

${ }^{24}$ Raja Ali Haji (1986), Kitab Pengetahuan Bahasa, Pekanbaru: Penelitian dan Pengkajian Nusantara; Bagian Proyek Penelitian dan Pengkajian Kebudayaan Melayu, Dikbud, p. 262.

${ }^{25}$ Raja Ali Haji (1986), Kitab Pengetahuan Bahasa, pp. 312-314.

${ }^{26}$ Jan van der Putten (2002), “On sex, drugs and good manners: Raja Ali Haji as lexicographer,” Journal of Southeast Asian Studies, Vol. 33, No. 3.

${ }^{27}$ Raja Ali Haji (1986), Kitab Pengetahuan Bahasa, pp. 268 \& 324.

${ }^{28}$ Raja Ali Haji (1986), Kitab Pengetahuan Bahasa, p. 120

${ }^{29}$ Raja Ali Haji (1886-1887), Tsamarat al-Muhimmah Dhiyafat li al Umara wa al-Kubara li Ahli al-Mahkamat, Lithographed on Lingga, pp. 58, 59, 69.

${ }^{30}$ Raja Ali Haji (1886-1887), Tsamarat al-Muhimmah Dhiyafat li al Umara wa al-Kubara li Ahli al-Mahkamat, p. 7.
} 
should commit to him by the basis of more as a religious reason, rather than simply a socio-political one. This view closely resembles Al-Mawardi's opinion that the obligation in establishing leadership is fardhu kifayah as well as jihad. ${ }^{31}$

RAH then mentions several mechanisms of king designation. Firstly, it is done through the pledge of allegiance (bai'at), by a commission that is trusted in electing a king through consultation and agreement. ${ }^{32}$ Secondly, the king is designed through istikhlaf (choosing one's own successor). About this mechanism, RAH refers to what Caliph Umar ibn al-Khattab did. Finally, it is because of a power (taghallub) that is a mechanism of the designation of someone as a king after showing his power in defeating his enemies. ${ }^{33}$

Moreover, he lists ten qualities and conditions that a ruler must meet: (1) a Muslim, (2) a responsible male, (3) being freedom, (4) being just, (5) competent in legal reasoning, (6) good sense of hearing, (7) good sense of seeing, (8) good sense of speaking (9) good physical organs /no physical defect, (10) having personal integrity, brave, and consistent in running governmental orders. ${ }^{34}$ These qualifications seem to look very ideal. However, according to RAH, they are important because of the very heavy and strategic functions of the ruler mainly pertaining to public needs. RAH provides an example of how many people would suffer as the consequences of a ruler's false decision. By contrast, myriad people would gain benefits as a result of his wise policies and right decisions.

RAH's political thoughts and his direct involvement in practical politics is generally based on his concept of "king demythologization." As mentioned in his Tuhfat al-Nafis, this cooncept serves as a ground of and colors his political thoughts. It has worked as a counter to the mythic perception which had been previously popularized by former rulers to Malay society. "King mythologization" is a concept of divine kingship as part of ruler's claims to be descendants of gods as well as a shadow of God on earth. The perception was inherited from the pre-Islamic belief that still clinged in Malay political thoughts. Many kings considered the concept to be the justification of their power and dignity of their reign and created an image that their accountability only to God, thus removing them from public scrutiny. The divine right of kings then served to sacralize monarchy and rulers.

This mythic form about the king was not only in the Malay community but also in other communities of Nusantara with some similarities. ${ }^{35}$ Referring to Islamic view, for RAH, a ruler is indeed a human being. He is a creature, a servant of God and is not free from various human negative trends, so that his behavioral patterns should refer to religious morals. The responsibility of a ruler is considered very serious so that it needs complete governmental instruments that can help him in performing his sovereignty. Therefore, a ruler, as RAH remarks, should keep learning or questing the knowledge and performing based on Quran, Hadis, and ijma ${ }^{36}$ RAH's thoughts on the demythologization of the king was a novel and brave concept in his contemporary that needs moral and intellectual bravery. This concept can be seen as the Islamic influences which were quietly unknown during the pre-Islamic period in Nusantara.

In the last chapter of Tsamarat al-Muhimmah, RAH provides ethical orientation for the ruling elites, that they should maintain their honor and self-esteem as leaders. There are three points that they have to keep: Firstly, taking care of the spirit i.e., the inner aspect of a human being. Since its very central position, the spirit affects the human physical sphere. Therefore, he insists that its maintenance is compulsory. Secondly, maintaining the health of the body. In this respect, he provides some advice about meal regulation and other biological needs. Finally, keeping credibility and self-esteem. ${ }^{37}$ Both are symbols of national self-image. A king must always become the pride of people. His good selfesteem will lead to increase their ethos of work and motivation to submit to his orders. This thought indicates a concept of a more fundamental and integral identity of mental, physics, and self-profile. In other words, morality and self-integrity become very urgent.

\footnotetext{
${ }^{31}$ Al-Mawardi (1973), Al-Ahkam al-Sulthaniyah wa al-Wilayat al-Diyanat, Cairo: Syirkah Maktabah wa Mathba'ah Mustafa al-Babi alHalabi wa Auladih, p. 5.

${ }^{32}$ Raja Ali Haji (1886-1887), Tsamarat al-Muhimmah Dhiyafat li al Umara wa al-Kubara li Ahli al-Mahkamat, p. 7.

${ }^{33}$ Raja Ali Haji (1886-1887), Tsamarat al-Muhimmah Dhiyafat li al Umara wa al-Kubara li Ahli al-Mahkamat, pp. 7-8.

${ }^{34}$ Raja Ali Haji (1886-1887), Tsamarat al-Muhimmah Dhiyafat li al Umara wa al-Kubara li Ahli al-Mahkamat, p. 8.

${ }^{35}$ A.C. Milner (1988), "Islam and Muslim State," in Islam in Southeast Asia, M.B. Hooker (ed), The Netherlands: E.J. Brill, p. 31

${ }^{36}$ Raja Ali Haji (1886-1887), Tsamarat al-Muhimmah Dhiyafat li al Umara wa al-Kubara li Ahli al-Mahkamat, p. 8.

${ }^{37}$ Raja Ali Haji (1886-1887), Tsamarat al-Muhimmah Dhiyafat li al Umara wa al-Kubara li Ahli al-Mahkamat, pp. 41,45 \& 47.
} 
Moreover, the tone of this work strengthens the conviction that a ruler is positioned as moral guides to his society. It emphasizes that his principal duty and the function of the state is to create an atmosphere conducive for religious practices so that each subject can meet his religious duties and be prepared for the Day of Judgment ${ }^{38}$ The leaders of such society, as Barnard mentions, has the additional responsibility to be a role model for his society and set the moral standards for them. ${ }^{39}$ Under the rule of a perfect ruler, the state also becomes perfect.

RAH also notes that positive law must be Islamic, ${ }^{40}$ but there are no fix reasons to conclude that he wants a theocratic reign because it contradicts his demythologization as well as there is no enough reason to say that he desires a monarchy. The reign that he means is not a tyrant nor absolute, but a constitutional reign that submits to a set of rules in governing the state according to the Qur'an and Sunnah. Nevertheless, as he knows, not all Syari'ah rules concerning the reign and mundane life issues are regulated in detail and therefore other jurisprudences have to be added through a process of legal reasoning (ijtihad).

RAH mentions that the function of a ruler can generally be differentiated into two fields even though they cannot be apart from each other. One is the mundane affairs and the other is the religious orders. Dualistic dividing between the profane and sacral (the mundane and hereafter) is better not understood as a dichotomy. They usually interact with each other. They can only be distinguished but cannot be separated. Each of these affairs is delegated to Wazir al-Azhim and Sheikh al-Islam (sultan) including all of its staff under them. ${ }^{41}$ In political practice at the Riau Kingdom, the function of the Wazir al-Azhim was held by the RJM that was called Yang Dipertuan Muda, resembling the function of Prime Minister.

Such a description of RAH's socio-political thoughts seems to suggest that he attempts to follow classical Muslim thinkers like al-Ghazali and al-Mawardi. In his Tsamarat al-Muhimmah and Muqaddimah fi Intizham, he seems to be affected by such "both teachers" of his political thoughts with a realistic Sunni background of factual politics in his contemporary. Al-Mawardi has discussed similar issues in his al-Ahkam al-Sultaniyah ${ }^{42}$ as well as al-Ghazali has talked about it in his Nasihat al-Mulk. ${ }^{43}$

RAH lived in the nineteenth-century, a transitional century between the middle age and the contemporary period in Islamic political thoughts. This era was identified by the decline and weakness of the Islamic world while spreading the West's influences in it. The contemporary Muslim thinkers at the time oriented to modernize and purify Islam and its various nuances. In civic issues, different currents or schools rose. Some of them tended to be traditional and anti-attitude toward whatever comes from the West and they wished to return to pure Islam. It also means to return to sovereignty patterns in the Prophet and the four Caliphs era (the Khulafa al-Rasyidin). They believed that Islam is a more holistic way of life, including in governmental issues, rather than a simple religion according to the Western perspective. Meanwhile, other schools wanted both purified Islamic teachings and possible consideration of such pure teachings adaptation with a new era in which its situation is so far different from the early centuries of Islam. RAH seems to be affected by the developing political concept at the time. He was fundamentally influenced by classical and middle age Muslim thinkers such as Al-Ghazali and Al-Mawardi as mentioned earlier.

\section{The Influence of Raja Ali Haji's Thoughts toward Malay Society}

As a result of RAH's contribution in Malay culture and language maintenance, Riau Kingdom was considered by Malays and Dutch to have maintained the culture and language of the highest and purest kind. ${ }^{44}$ Andaya and Matheson also mention that RAH's prestige "among the Malay speaking

\footnotetext{
${ }^{38}$ Raja Ali Haji (1304), Muqaddimah fì alIntiz̄ām al-Wazāif al-Mulk Khusūsan ilā Mawlāna wa Șāhibinā Yang Dipertuan Muda Raja Ali alMudabbir li al-Bilād al-Riauwiyyah wa Sāir Dāirat, Lingga: Pejabat Kerajan Lingga, p. 3.

${ }^{39}$ Timothy P. Barnard (1994), "Taman Penghiburan : Entertainment and the Riau Elite in the Late 19th Century," JMBRAS, Vol. 67, pp. 1746.

${ }^{40}$ Raja Ali Haji (1886-1887), Tsamarat al-Muhimmah Dhiyafat li al Umara wa al-Kubara li Ahli al-Mahkamat, p. 29.

${ }^{41}$ Raja Ali Haji (1886-1887), Tsamarat al-Muhimmah Dhiyafat li al Umara wa al-Kubara li Ahli al-Mahkamat, pp. 13-14.

42 Al-Mawardi (1973), Al-Ahkam al-Sulthaniyah.

${ }^{43}$ Al-Ghazali (1978), al-Tibr al-Masbuk fi Nasihat al-Mulk, Beirut: Dar ibn Zaidan.

${ }^{44}$ Virginia Matheson (1983), "Questions Arising from a Nineteenth-Century Riau Syair," Review of Indonesian and Malaysian Affairs, Vol. 17, p. 5.
} 
population of the area was high and he was considered a scholar of great renown among his countryman." ${ }^{45}$ The era of the $8^{\text {th }}$ until the $10^{\text {th }}$ RJM, began to witness the influence of his thoughts. As a religious scholar, a jurisprudences expert, and a leading advisor of the RJM, RAH provided the intellectual stimulation to the kingdom through the teaching process and the promotion of Islam. At the same time, he was also a prolific author who displayed sensitivity toward the new kind of worldview and ethos through his intellectual works.

By the mid-nineteenth century, under RAH's advisory the RJMs of the Penyengat linked kingship and religion. RJMs patronage of the mosque and tariqat and their management in the two areas showed their identification with Islam in both its canonical and mystical aspects. The RJMs also utilized the three institutions of mosque, tariqat, and kingdom to strengthen social integrity and cohesion. ${ }^{46}$

With the help of RAH, Riau began to fulfill a new niche in Malay society by promoting religiously pious and literate elite who could guide the community to new prosperity based on Islamic principles. While Singapore's elites became gradually influenced by the colonial new lifestyle instilled by the English, Riau persisted being the protector of Malay heritage which was deeply rooted in Islamic teaching and maintained its reputation as a site where the true Islamic religion flourished, encouraged by the piety of both the RJM and Sultan. ${ }^{47}$

The most notable aspect of the growing Islamic legitimation of a ruler can be seen in the literature. Many rulers and members of the community began to express themselves through a wide range of Malay forms of literature mostly poems. Some composed didactic works in a climate of Islamic reformism, others were engaged in the translation of religious texts, which meant to pave the way to closely associate man and God. The works reflected the growing intensity of religious belief between a good ruler with a pious belief and his subjects. ${ }^{48}$ The RJM, Raja Ali, wrote a poem, Syair Nasehat, meant to advise young men, emphasizing on proper behavior, correct conduct, graceful expression, and observance of religion and custom. ${ }^{49}$ Another RJM, Raja Abdullah, composed four poems with the same tone. Another distinguished court member, Haji Ibrahim, criticized the disobedience of youth to the Malay tradition, and their reluctance to learn adat and adab (cultured behavior).$^{50}$ Indeed, the writings of RAH were both stimulants and epitomes of this renaissance in the Malay literature.

Tuhfat al-Nafis frequently mentions Penyengat as a center of Islamic scholarship and territory ruled by RJMs who were devout Muslims. Under RAH's advisory, Raja Ali bin Ja'far instituted some important things which brought glory to the name of realm and strengthened the religion. Such a situation has been recorded in Tuhfat al-Nafis:

During his reign he upheld the Islamic faith, attending the mosque on Fridays and ordering women to be veiled. He completed the construction of the mosque... Many religious scholars came. After consultation with his cousin, Raja Ali Haji, he paid their expenses and ordered all state officials to study religion, recite religious works, and to improve their recitation of the glorious Koran. He loved the quest for knowledge. His cousin, Raja Ali Haji, selected several learned men, like Sayyid Abdullah Bahrain and others, to settle and teach in Penyengat for a year... He exiled all malefactors and forbade gambling, cockfighting, the mixing of unmarried men and women. ${ }^{51}$

Raja Ali was also a devoted follower of Naqsyabandiyah Order. All the princess followed him studying mysticism. ${ }^{52}$ Under his rule, the tareqat became popular on Penyengat. By the mid-1850s, Penyengat was considered as a well ordered and attractively settled center. He keeps living simply with his exhortation. He asked not to be buried in the customary pomp of royal funeral. Thus, he was the first RJM from Riau to have a simple burial. His successor, Raja Abdullah, was also a devout

\footnotetext{
45 Andaya \& Matheson (1979), "Islamic Thought and Malay Tradition,” p. 115.

${ }^{46}$ M Virginia Matheson (1989), "Pulau Penyengat: Nineteenth-Century Islamic Centre of Riau," Archipel, Vol. 37 , No. 1.

${ }^{47}$ Raja Ali Haji (1965), Tuhfat al-Nafis, pp. 340-50.

${ }^{48}$ Timothy P. Barnard (1994), "Taman Penghiburan."

${ }^{49}$ Raja Ali other's work was Hikayat Negeri Johor.

${ }^{50}$ Andaya \& Matheson (1979), "Islamic Thought and Malay Tradition," p. 121.

${ }^{51}$ Raja Ali Haji (1965), Tuhfat al-Nafis, p. 346-47.

${ }^{52}$ Raja Ali Haji (1965), Tuhfat al-Nafis, p. 347.
} 
adherent of the Naqsyabandiyah Order. The following RJM, Muhammad Yusuf Ahmadi, even became the leader of the same order. ${ }^{53}$

Based on RAH's suggestions, the $10^{\text {th }}$ RJM, Raja Muhammad Yusuf Ahmadi (1859-1899), built a huge library and purchased religious books from India, Cairo, Mecca, and Medina. ${ }^{54}$ and provided printing company. ${ }^{55}$ The presence of the library and printing had encouraged the creativity of Riau authors as well as accelerated writing activities among the intellectuals who coordinated themselves in Rusydiah Club (an association of writers established in the late nineteenth century and active from the 1890s until the 1920s). ${ }^{56}$ Moreover, the printing had been utilized effectively to spread the Malay works and religious texts including those of RAH to reach a broader audience in the Malay Archipelago. Treatises on political ethics of the ruler, Muqaddimah fi Intizam and Tsamarat al Muhimmah written by RAH were printed at Lingga. Putten pointed out RAH's influence and reputation with the benefits of the printing press as follows:

Through the works, he wrote in a period of about twenty-five years (1847-1872), he established a literary tradition that was continued by members of Rusydiah Club. He gained his reputation through the publication of his poems and other works. He was indeed preoccupied with the benefits a printing press held for not only his reputation but also that of the Penyengat court. Therefore, it is not surprising that at least two of the four surviving products printed on the lithographic press in Penyengat were written by Raja Ali Haji. ${ }^{57}$

Barbara and Matheson affirm that the influence of RAH's thoughts had resonated for four decades after his life, and Dutch acknowledged his leadership of the Penyengat circle. ${ }^{58}$ The influences of RAH's political thoughts did not only reverberate in Riau but resonated until neighbor states especially Johor and Trengganu. Sham remarks:

His works on state government such as Tsamarat al-Muhimmah were well-known amongst the kings and elites in Johor and Trengganu. These works became the foundation of administration for Malays during that period, and Raja Ali Haji was an expert who became an important source of reference for the Malay kings. ${ }^{59}$

In 1868, when Abu Bakar would be designated as Sultan of Johor, he dispatched envoys to consult RAH on a suitable choice, and asked him about Malay customary law and conventions, and whether he could accept the title of raja. ${ }^{60}$ Then, he also invited RAH to his inauguration as a ruler in 1868 and drove him back to Riau. RAH lent him several books, including Tsamarat al-Muhimmah and Salsilah Melayu Bugis. Sham argues that Johor's Constitution in 1895 which was under Abu Bakar's administration included some of RAH's advice, especially concerning qualities that a ruler must meet. ${ }^{61}$ Sham writes:

There were some parts of Johor's Constitution of 1895 which were influenced by Tsamarat al-Muhimmah, for instance, that a ruler must be of male and Muslim. However, the constitution added that he must be the descendant of Sultan Abu Bakar. If there were none, it was permitted from the descendant of Temenggung Ibrahim...Appointment of ministers and state officials was conducted based on the concept of ahlu al-halli wal 'aqdi as found in Tsamarat al-Muhimmah...Clauses on court

\footnotetext{
${ }^{53}$ Virginia Matheson (1989), "Pulau Penyengat."

${ }^{54}$ Abu Hassan Syam (1993), Puisi-puisi Raja Ali Haji, Kuala Lumpur: Dewan Bahasa dan Pustaka, p. 27.

${ }^{55}$ It was found in 1894 and named Marthba'ah Riauwiyah or it is also called Marthba'ah Ahmadiyah.

${ }^{56}$ Hafiz Zakaria and Wiwin Oktasari (2017), "From Riau To Singapore: a Content Analysis of the Rushdiah Club'S Major Published

Writings (Ca. 1890-1950)," UMRAN - International Journal of Islamic and Civilizational Studies, Vol. 4, No. 3, pp. 11-25.

${ }^{57}$ Jan van der Putten (1997), "Printing in Riau: Two Steps Toward Modernity," Bijdragen, Vol. 153, No. 4, pp. 717-736.

${ }^{58}$ Andaya \& Matheson (1979), "Islamic Thought and Malay Tradition," p. 123.

${ }^{59}$ Abu Hassan Syam (1993), Puisi-puisi Raja Ali Haji, Kuala Lumpur: Dewan Bahasa dan Pustaka, p. 270.

${ }^{60}$ R.O. Winstedt (2016), “A History of Johor (1365-1895 A.D.),” Journal of the Malayan Branch of the Royal Asiatic Society, Vol. 10, No. 3, pp. 1-167.

${ }^{61}$ Abu Hasan Sham (1996), "Karya Raja Ali Haji, Tinjauan dari Perspektif Hukum," Paperwork, Symposium on Raja Ali Haji, Penyrengat, 1-31 October 1996, p. 27.
} 
meetings were also based on Tsamarat al-Muhimmah among others on oaths, keeping minutes of meetings, etc. ${ }^{62}$

Sham also remarks:

Trengganu's Constitution, Itqam al-Muluk bi Ta'dil al-Suluk, was also influenced by Tsamarat al-Muhimmah, that a ruler must be of the male sex, having personal integrity based on Islamic teaching, appointed from the descendant of the former king, but in certain circumstances, he might be elected by the parliamentary members, run the government following ministers' advice, and have parliamentary board to whom he and his ministers should listen to and obey. ${ }^{63}$

Since RAH is acknowledgeable in religion, history, literature, and law, his reputation widespread. His works reached broader readers than the small society in Penyengat. Unlike his contemporary, Munshi Abdullah who was an isolated voice, he was a broadly honored religious scholar whose thoughts held by most educated Malays. Covering the entire Malay world and rooted deeply in Islamic teaching, his outstanding work, Tuhfat al Nafis, has established his reputation in Malay historiography. His book, Bustan al-Katibin was also used with some success, not only in Riau but also in Johor and Singapore schools. His poem, Syair Sultan Abdul Muluk, was published in 1845 by a Singapore bookshop, and then republished by his friend, Roorda van Eysinga, with a Dutch translation in Tijdschrift voor Nederlandsch Indie in 1847, 'so his friend would become famous in the east and the west'. Meanwhile, Gurindam Duabelas was published in the distinguished Dutch journal of the Batavian Society in 1854. His other poems were also published in the Journal of the Bataviaasch Genootschap in $1853 .{ }^{64}$

The efforts of RAH as a pioneer in different fields of life and scientific disciplines factually yielded real results. From his cadres, some authors appeared: linguists, poets, diplomats, religious scholars, and other intellectuals. In his contemporary, RAH seems to be popular as a "single fighter" in the fields of thought, culture, and literature. However, the seeds that he has sown have produced the fruits. Some scholars and authors were born like his son, Raja Hasan, his daughters, Raja Syafi'ah and Raja Kalsum. There were also Raja Abdul Mutalib and Raja Muhammad Taher who were in the same generation with his son. The next generations were his grandsons: Raja Abdullah, Raja Ahmad Tabib, Khalid Hitam, and Raja Aisyah Sulaiman. There were also Khadijah Terung, Sulaiman binti Ambar, Raja Ali Kelana, Badriah M.Taher, and Raja H. M. Said who were in the same generation with his grandsons. The nineteenth until the beginning of the twentieth century witnessed a cultural and literary renaissance in Riau. ${ }^{65}$ Therefore, it is not surprising that H.C. Klinkert, a Bible translator, collected over 90 manuscripts during his short stay in Riau. Besides, until 1913, when the Riau Sultanate was abolished, 137 works consisting of 46 manuscripts and 91 printed books, the work of 70 Riau writers, had been documented by Hamidy. ${ }^{66}$ Their works were deeply rooted in Islamic teachings and Malay traditions. ${ }^{67} \mathrm{RAH}$ seems to agree with Imam al-Ghazali's opinion about "the authority of pen" that it is "mightier than the sword, mightier than ten thousand words' ${ }^{68}$ Using different redaction, RAH in his introduction of Bustan al-Katibin attractively stated:

Every action performed by a sword can be performed by a pen

But the actions of a pen cannot be performed by a sword

And thousands of swords which have been drawn

With the scratch of the pen are sheathed. ${ }^{69}$

\footnotetext{
${ }^{62}$ Sham (1996), "Karya Raja Ali Haji, Tinjauan dari Perspektif Hukum,” pp. 27-28.

${ }^{63}$ Sham (1996), "Karya Raja Ali Haji, Tinjauan dari Perspektif Hukum," p. 28.

${ }^{64}$ Jan van der Putten (1997), "Printing in Riau: Two Steps Toward Modernity," Bijdragen, Vol. 153, no. 4, pp. 719-721

${ }^{65}$ Muhammad Yusoff Hashim (1992), Pensejarahan Melayu, Kajian tentang Tradisi Sejarah Melayu Nusantara, Kuala Lumpur: Dewan Bahasa dan Pustaka Kementerian Pendidikan Malaysia, p. 467.

${ }^{66}$ UU Hamidy (1985), Naskah Melayu Kuno Daerah Riau, Pekanbaru: Bumi Pustaka.

67 Jan van der Putten (1997), "Printing in Riau: Two Steps Toward Modernity," Bijdragen, Vol. 153, no. 4, p. 721; Helmiati (2008),

Genealogi Intelektual Melayu: Tradisi dan Pemikiran Islam Abad ke-19 di Kerajaan Riau Lingga, Pekanbaru: Suska Press, pp. 60-115.

${ }^{68}$ W. Montgomery Watt (1953), The Faith and Practice of Al-Ghazali, London: G Allen and Unwin, p. 140.

${ }^{69}$ Raja Ali Haji (1983), Bustan al Katibina Lis Subyanil Muta'allimin.
} 


\section{Concluding Remarks}

RAH has played a prominent role in nurturing Islamic and socio-political thought in Riau and beyond. Through his thoughts, he strove to re-orientate tradition and political culture in the Malay community that was previously mixed and syncretized with mythic perception and superstitious elements. $\mathrm{He}$ attempted to awaken the society from their slumber to meet the challenges of the Malays' malaise as well as the Western domination of the world. He put religion as the basis and determinant factor of the intellectual tradition and synthesized the culture and politics with Islam. The late nineteenth-century has witnessed the influences of his Islamic thoughts which spanned nearly four decades after his death. The influence of his political thoughts reverberated not only in the Riau Malay kingdom, but also in the neighboring states like Johor and Trengganu. His political thoughts, mainly written in Tsamarat al-Muhimmah, were much more influential than those of Al-Mawardi written in his book, Al Ahkam al-Sultaniyyah. This finding challenges the earlier assumption that Al-Mawardi's political thoughts were more influential in the Malay world.

\section{References}

Al-Ghazali (1978), al-Tibr al-Masbuk fi Nasihat al-Mulk, Beirut: Dar ibn Zaidan.

Al-Mawardi (1973), Al-Ahkam al-Sulthaniyah wa al-Wilayat al-Diyanah, Cairo: Syirkah Maktabah wa Mathba'ah Mustafa al-Babi al-Halabi wa Auladih.

Andaya, Barbara W., \& Matheson, Virginia (1979), "Islamic Thought and Malay Tradition: The Writing of Raja Ali Haji of Riau (ca. 1809-ca. 1870)," in Perception of the Past in Southeast Asia, Anthony Reid \& David Marr (eds.), Singapore: Heinemann Education Book [Asia] Ltd.

Barnard, Timothy P (1994), "Taman Penghiburan : Entertainment and the Riau Elite in the Late 19th Century," JMBRAS, Vol. 67, 17-46.

Hadi W. M., \& Abdul (1985), Sastra Sufi: Sebuah Ontologi, Jakarta: Pusataka Firdaus.

Haji, Raja Ali (1886-1887), Tsamarat al-Muhimmah Diyafat li al Umara wa al-Kubara li Ahli alMahkamat, Lithographed on Lingga.

Haji, Raja Ali (1965), Tuhfat al-Nafis, Enche Munir Ali (trans.), Singapore: Malaysian Publications Ltd.

Haji, Raja Ali (1983), Bustan al Katibina Lis Subyanil Muta'allimin, Yayasan Kebudayaan Indera Sakti Pulau Penyengat, Koleksi Naskah, no.19.

Haji, Raja Ali (1986), Kitab Pengetahuan Bahasa, Pekanbaru: Penelitian dan Pengkajian Nusantara; Bagian Proyek Penelitian dan Pengkajian Kebudayaan Melayu, Dikbud.

Haji, Raja Ali (1304), Muqaddimah fi alIntizām al-Wazāif al-Mulk Khusūsan ilā Mawlāna wa Șāhibinā Yang Dipertuan Muda Raja Ali alMudabbir li al-Bilād al-Riauwiyyah wa Sāir Dāirat, Lingga: Pejabat Kerajan Lingga.

Haji, Raja Ali (2003), Gurindam Dua Belas, Pekanbaru: UNRI Press.

Haji, Raja Ali (1983), Syair Siti Shianah, Pulau Penyengat: Yayasan Kebudayaan Indra Sakti, Koleksi Naskah, no. A 13.

Haji, Raja Ali (1983), Suluh Pegawai, Yayasan Kebudayaan Indra Sakti Pulau Penyengat, Koleksi Naskah no. B 13.

Haji, Raja Ali, Syair Hoekoem Nikah, Univ. Bibliotheek Leiden, Cod. Or. Klinkert. 
Journal of Al-Tamaddun, Vol. 16 (2), 2021, 99-109

Hamidi, U. U. et al. (1986), Syair Suluh Pegawai: Hukum Nikah, Karangan Raja Ali Haji, Pekanbaru: Departemen Pendidikan dan Kebudayaan.

Hamidi, U. U. et al. (1985), Naskah Melayu Kuno Daerah Riau, Pekanbaru: Bumi Pustaka.

Hashim, Muhammad Y. (1992), Pensejarahan Melayu, Kajian tentang Tradisi Sejarah Melayu Nusantara, Kuala Lumpur: Dewan Bahasa dan Pustaka.

Helmiati (2008), Genealogi Intelektual Melayu: Tradisi dan Pemikiran Islam Abad ke-19 di Kerajaan Riau Lingga, Pekanbaru: Suska Press.

Jabbar, Fakhrunnas M. A. (1985), "Catatan Malam Raja Ali Haji: Mengarang dengan Rujukan alQuran dan Hadis," Berita Buana, Tuesday, 21 May.

Junus, Hassan (2002), Raja Ali Haji: Budayawan di Gerbang Abad XX, $2^{\text {nd }}$ edition, Pekanbaru: Unri Press.

Maier, Hendrik M. J. (2001), "Raja Ali Haji dan Hang Tuah: Arloji dan Mufassar," SARI : Jurnal Alam dan Tamadun Melayu, Vol. 19, No. 1, 159-78.

Malik, Abdul \& Shanty, Isnaini L. (2017), "Personal Character Index in the Works of Raja Ali Haji," International Journal of Information Technology and Business Management, Vol. 58, No.1, 22-34.

Matheson, Virginia (1983), "Questions Arising from a Nineteenth Century Riau Syair," Review of Indonesian and Malaysian Affairs, Vol. 17, 1-59.

Matheson, Virginia (1989), "Pulau Penyengat : Nineteenth-Century Islamic Centre of Riau," Archipel, Vol. 37, No. 1, 153-172.

Milner, A.C. (1988), "Islam and Muslim State," in Islam in Southeast Asia, M. B. Hooker (ed.), Netherlands: E.J. Brill.

Palawa, Alimuddin H. (2003), "The Penyengat School: A Review of the Intellectual Tradition in the Malay-Riau Kingdom," Studia Islamika, Vol. 10, No. 3, 95-123.

Palawa, Alimuddin H. (2020), Pemikiran Politik Raja Ali Haji Perspektif Etis dan Sufistik, Depok: Rajawali Pers.

Putten, J. \& Al Azhar (1992), "Four Malay letters from Raja Ali Haji to Von De Wall," Journal of the Humanities and Social Sciences of Southeast Asia, Vol. 148, No. 3, 521-528.

Putten, Jan van der (1997), "Printing in Riau; Two Steps Toward Modernity," Bijdragen, Vol. 153, 717-736.

Putten, Jan van der (1997), "Versified Awai Verified: Syair Awai by Raja Ali Haji," Indonesia and the Malay World, Vol. 72, 99-133.

Putten, Jan van der (2002), "On sex, drugs and good manners: Raja Ali Haji as lexicographer," Journal of Southeast Asian Studies, Vol. 33, No. 3, 415-430.

Sham, Abu Hasan (1996), "Karya Raja Ali Haji: Tinjauan dari perspektif Hukum," Seminar paper in celebrating Raja Ali Haji's day, Pulau Penyengat, 31 October.

Sham, Abu Hasan (1993), Puisi-puisi Raja Ali Haji, Kuala Lumpur: Dewan Bahasa dan Pustaka. 
Nurturing Islamic and Socio-political Thoughts in Riau and Beyond (Exploring Raja Ali Haji's Works) Sham, Abu Hasan (1996), "Karya Raja Ali Haji, Tinjauan dari Perspektif Hukum," Paperwork, Symposium on Raja Ali Haji, Penyrengat, 31 October.

Winstedt, R.O. (2016), “A History of Johor (1365-1895 A.D.)," Journal of the Malayan Branch of the Royal Asiatic Society, Vol. 10, No. 3, 1-167.

Watt, W. Montgomery (1953), The Faith and Practice of Al-Ghazali, London: G Allen and Unwin.

Zakaria, Hafiz, and Wiwin Oktasari (2017), "From Riau To Singapore: a Content Analysis of the Rushdiah Club'S Major Published Writings (Ca. 1890-1950)," UMRAN - International Journal of Islamic and Civilizational Studies, Vol. 4, No. 3, 11-25. 
Journal of Al-Tamaddun, Vol. 16 (2), 2021, 99-109 